\title{
La basílica de santa María de Elche: proyecto clasicista en la arquitectura del siglo XVII
}

\author{
CARLOS ENRIQUE NAVARRO-RICO \\ Universitat de València
}

Recibido: 11-03-2019

Aprobado: 28-06-2019

\section{RESUMEN}

La basílica de santa María de Elche se construyó en un dilatado periodo de tiempo (1673-1784), si bien la totalidad de su fábrica es deudora de la concepción del proyecto original. Este fue elaborado por el arquitecto Francisco Verde, siendo continuado por Pedro Quintana y rediseñado por Juan Fauquet. En este artículo se explora dicho proyecto en el marco de la arquitectura seiscentista, así como se aporta documentación inédita sobre los primeros años de construcción y sus artífices.

PALABRAS CLAVE: Francisco Verde / Pedro Quintana / Juan Fauquet / Arquitectura barroca / Ingeniería hidráulica.

\section{ABSTRACT}

The church of Santa Maria (Elche) was built on a lengthy period of time, although the construction is based on the conception of the original project, designed by the architect Francisco Verde, continued by Pedro Quintana and redesigned by Juan Fauquet. This article explores the project in the context of the architecture of that time and provides new documentation about its architects and the early years of the construction.

KEY WORDS: Francisco Verde / Pedro Quintana / Juan Fauquet / Baroque architecture / Hydraulic engineering.

\footnotetext{
* La realización del presente trabajo ha sido posible gracias a la financiación de la Generalitat Valenciana y el Fondo Social Europeo a través de una beca predoctoral, que disfrutamos bajo la dirección de la doctora Yolanda Gil Saura. A ella y al personal del Archivo Histórico Municipal de Elche les agradecemos su colaboración. Este trabajo se enmarca en el proyecto I+D financiado por el Ministerio de Economía, Industria y Competitividad, HAR2017-83070-P: Geografias de la movilidad artística. Valencia en Época Moderna.
} 
La basílica de santa María de Elche (Fig. 1) constituye un destacado hito de la arquitectura clasicista de finales del siglo $\mathrm{XVII}^{1}$, formando parte de un grupo de grandes empresas edilicias —entre las que se encuentran san Nicolás de Alicante o la Seo de Xàtiva - caracterizadas por sus soberbias proporciones, alzados clasicistas y construcción en cantería. Frente a la albañilería que se popularizaba por entonces en el entorno valenciano, la opción canteril exigía la participación de experimentados artífices, cuya versatilidad les hacía a su vez protagonistas de la ejecución de importantes obras de ingeniería hidráulica, como pantanos y conducciones de aguas.

Fue este el caso de Francisco Verde y Pedro Quintana, primeros maestros de la iglesia de santa María y cuyo depurado lenguaje siguió rigiendo las intervenciones de los diferentes artífices que dirigieron su dilatada edificación (1673-1784), condicionada además por su naturaleza de escenario del Misteri d'Elx, extraordinario drama sacro de tradición inmemorial. De la actividad de ambos arquitectos derivan los datos que aportamos, que invitan a replantear no solo el proceso constructivo de la iglesia, sino también su papel en la cultura arquitectónica delmomento.

\section{El deterioro de la anterior fábrica}

El templo anterior al actual y que llegó en pie al siglo XVII fue el concluido hacia 1566 por Julián de Alamiques, pero sus importantes problemas estructurales exigieron numerosas intervenciones, y entre ellas encontramos involucrados a Verde y Quintana².

Francisco $\operatorname{Verde}^{3}$ consta como feligrés de esta parroquia de santa María en

\footnotetext{
1 Sobre este templo, R. NAVARRO MALLEBRERA, Los arquitectos del templo de santa María de Elche, Caja de Ahorros, Alicante, 1980; Y. SPAIRANI-BERRIO, La basílica de Santa María de Elche. Análisis histórico, arquitectónico y constructivo. Estudio diagnóstico (Tesis doctoral), Universidad de Alicante, 2016.

2 J. CASTAÑO GARCÍA, "Algunos datos sobre el tercer templo de santa María de Elche (1492?-1672)”, Pobladores de Elche, n. ${ }^{\circ} 10,1988$, p. 79-89.

3 Se le ha atribuido origen genovés, que no hemos podido confirmar. Para Tormo fue uno de los arquitectos más importantes del siglo XVII en el "levante", Bérchez le considera "uno de los más significativos representantes del último clasicismo monumental seiscentista valenciano", mientras que Navarro Mallebrera lo veía como "el primer arquitecto barroco del reino". E. TORMO Y MONZÓ, Levante, Calpe, Madrid, 1923, p. 294. J. BÉRCHEZ, Arquitectura barroca valenciana, Bancaja, Valencia, 1993, p. 38. R. NAVARRO MALLEBRERA, Los arquitectos..., op. cit., pp. 44-45.
} 


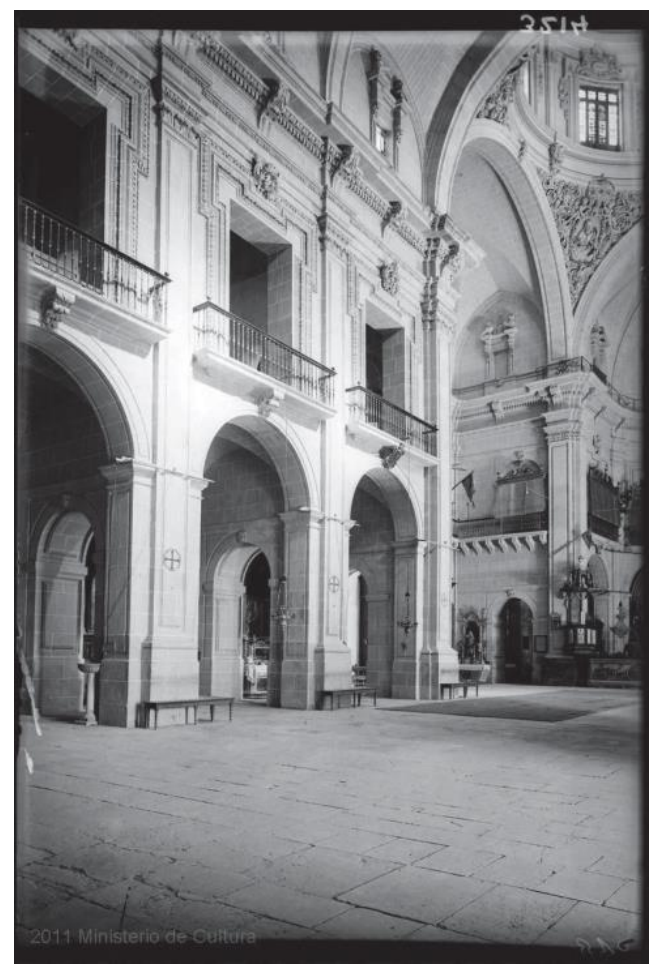

Fig. 1. Iglesia de santa María, de Elche (Foto: António Passaporte. Archivo Loty, IPCE, Ministerio de Cultura).

1635, y a pesar de su traslado a Enguera (Valencia) hacia $1636^{4}$, permaneció muy vinculado a la misma. Así, le vemos en un cabildo parroquial de agosto de 1642 , actuando como testigo junto al cantero Ginés Irles y señalándose ambos como "de Elig"5; al parecer, acudieron para evitar que al picapedrero le fuera revocado el encargo anual de tapar las goteras, que últimamente había desatendido.

En 1635, Verde bautizó en santa María a su hijo Esteban. M.J. LÓPEZAZORÍN, "El claustro del Real monasterio del Puig de Santa María y la participación del P. José Sanchis y los arquitectos Francisco Verde y Juan Pérez Castiel", Obra mercedaria, n. $^{\circ}$ 224, 1998, p. 207-230. Francisco Verde aparece avecindado en Enguera en 1646. P. GARZÓN SERRANO, "Enguera en el vecindario de 1646", en Aproximación a la historia de Enguera, Enguera, Ayuntamiento, p. 217-234.

$5 \quad$ A Ginés Irles se le encargó en diciembre de 1646 el reconocimiento de dos pilares muy deteriorados, cobrando por rehacer uno de ellos en junio de 1649. A su muerte en 1662, fue su hijo homónimo quien se hizo cargo de las reparaciones rutinarias de la parroquia, viviendo junto a Verde el derrumbe de esta antigua fábrica y la elevación de la nueva. La reciente transcripción del libro de fábrica nos ha permitido acceder a estas noticias: J. CASTAÑO GARCÍA (ed.), Llibre de la fàbrica de senta Maria de la Vila de Elig (1592-1699), Universidad de Alicante, Alicante, 2015, pp. 148-149, 167, 211, 262. Algunas se desglosan también en Y. SPAIRANI-BERRIO, op. cit, p. 94-105. La viuda del padre, Clara Marco, testó en noviembre de 1681 pero con "bona salud", nombrando herederos a sus hijos. Archivo Histórico Municipal de Elche [AHME], sig. SHPN 261, f. 102-104v. 
La continuada presencia de Verde en Elche se explica porque, en 1643, fue nombrado "sogueador y agrimensor" municipal ${ }^{6}$, y por ello delineó los partidores de riego en $1666^{7}$, proyectó un trasvase de agua desde el Júcar a la huerta ilicitana en $1668^{8}$, o redactó en 1670 un memorial como "maestro matemático del rey" para la desviación de las aguas del pantano ${ }^{9}$. Estas noticias, así como que la ciudad de Valencia le solicitara en 1653 participar junto con Francisco Serrano y Pedro Leonart en el proyecto de modificación del caudal del río Cabriel para su incorporación al Turia $^{10}$, dan cuenta de su faceta y especial cualificación como ingeniero hidráulico, común a muchos de los artífices del momento e inseparable de su actividad como arquitectos.

Como decíamos, el arquitecto no fue ajeno al lastimoso estado de la antigua iglesia, que además también afectaba a sus imágenes y enseres, y provocó que la patrona de la villa, la Virgen de la Asunción, fuese trasladada a la ermita de san Sebastián en diferentes ocasiones desde al menos 1646 hasta 1649. Por este motivo, el 8 de diciembre de 1656 los parroquianos planteaban la construcción de una capilla para ella, ordenando que "es cride amestre Verdeperaque esvejaen lopuesto hon se hadefer" y acordando unos días después su construcción ${ }^{11}$. Aunque no parece que se concretara ni se dieran las trazas, en la idea subyace la renovación y exaltación litúrgica y artística del culto mariano, propia del ánimo contrarreformista y también de la cada vez más extendida causa inmaculista, pues no pasa inadvertida la fecha de la reunión ${ }^{12}$.

\footnotetext{
R. NAVARRO MALLEBRERA, Los arquitectos..., op. cit., p. 45. 7 J. HIDALGO TABLADA, El agrónomo: manual de riegos y aplicación de las aguas de aluvión al cultivo de ques a Elx, Universidad de Alicante, Alicante, 1991, p. 16, su apuradísima técnica. Por su parte, el erudito P. IBARRA RUIZ, Estudio acerca de la institución del riego de Elche y origen de sus aguas, Jaime Ratés, Madrid, 1914, p. 147, afirmaba que se había hecho "en modo tal y tan perfectamente, que nadie hasta hoy, que sepamos, ha puesto mano en su célebre partición". En el AHME se conservan el Libro que contiene la delineación de los partidores de las aguas de la Acequia Mayor de esta villa, hecho por el matemático Francisco Verde, 1666, sig. H 23 32; y el Libro y advertencias sobre el buen gobierno de los partidores del agua de la Acequia Mayor, 1666, sig. H 2333.

8 Por ser "persona de molta experiència i inteligència en esta matèria", AHME, sig. b 17, s/f. A. LÓPEZ GÓMEZ, "Presas y canales de riego en los siglos XVI y XVII", en Hitos históricos de los regadíos españoles, A. GIL OLCINA y A. MORALES GIL, Ministerio deAgricultura, Madrid, 1992, p. 123.

9 R. NAVARRO MALLEBRERA, Los arquitectos..., op, cit., pp. 45-46. Véase G. JAÉN Y URBAN, D'aigua ..., op. cit., p. 27.

10 E.L. BURRIEL DE ORUETA, La Huerta de Valencia: zona sur, Alfons el Magnànim, Valencia, 1971, p. 154.

11 J. CASTAÑO GARCÍA, "Algunos datos sobre el tercer templo...”, op. cit., p. 82-83; J. CASTAÑO GARCÍA, Llibre de la fàbrica..., op. cit., pp. 193-195.

12 Véanse los estudios recogidos en Intacta María, catálogo de la exposición (Valencia, Museo de Bellas Artes, 2017), Pablo González (ed.), Valencia, 2017.
} 
Unos años después también se documenta en esta fábrica a Pedro Quinta$\mathrm{na}^{13}$, por entonces trabajando en la sacristía de san Nicolás de Alicante. La parroquia ilicitana recurrió a él entre 1663 y 1666 para que evaluara el estado del templo, señalando el arquitecto en todas las ocasiones el importante riesgo que corría la integridad del edificio. Todavía en septiembre de 1666 reflejaba, en un memorial de su puño y letra, los daños y reparaciones que precisaba, cifradas en unas 350 libras. Aunque en octubre se ordenó la puesta en marcha de las reformas, parece que no se completaron dado el penoso estado económico de la fábrica, que "no té dinés ninguns", y aun en 1672 no se habían realizado ${ }^{14}$.

Por este motivo y de manera irremediable, unos fuertes temporales provocaron el desplome el 30 de mayo de 1672 de parte de las bóvedas. Las crónicas describen cómo, mientras Irles y otros operarios apuntalaban la estructura, cayó otro de los tramos, estando presente el propio Francisco Verde, y todos "llenos de susto y cuasi enteramente ciegos de la polvareda, se hincaron de rodillas y no cesaron de dar gracias [...] por haber salido salvos de tan crítica situación" ${ }^{\prime 15}$.

\section{El nuevo templo: cuadrillas y paralización}

Tras el derrumbe, la parroquia decidía encargar a Francisco Verde la construcción de un nuevo templo, y en marzo de 1673 el arquitecto entregó las trazas. Las obras comenzaron el 2 de julio por los pies de la iglesia, y Verde dirigió la cimentación exterior de esta parte, de los pilares interiores y parte de los muros del lado del Evangelio hasta su muerte, el 6 de abril de $16744^{16}$. Un día antes había testa-

\footnotetext{
13 Quizá el mismo que antes de 1660 trabajaba en la parroquial de Torralba de los Frailes (Zaragoza). Es probable el parentesco con el Pedro Quintana activo entre 1586 y 1590 en Báguena (Teruel) y Moneva (Zaragoza). J. MARTíNEZ VERÓN, Arquitectos en Aragón. Diccionario histórico, Fernando el Católico, Zaragoza, 2001, vol. III, p. 375.

14 J. CASTAÑO GARCÍA, “Algunos datos sobre el tercer templo...”, op. cit., p. 84-86; J. CASTAÑO GARCÍA, Llibre de la fàbrica..., op. cit., pp. 215-216, 227-229, 271-273.

15 J. FUENTES Y PONTE, Memoria histórico-descriptiva del Santuario de Nuestra Señora de la Asunción en la ciudad de Elche, Tipografía mariana, Lérida, 1887, p. 84. El suceso se narra en primera persona en un antiguo manuscrito. AHME, sig. b 70, f. 283.

16 J. FUENTES Y PONTE, op. cit., 1887, p. 84. Verde estuvo trabajando hasta pocos días antes de morir, pues el 4 de abril recibía 300 reales a cuenta de su salario. R. NAVARRO MALLEBRERA, Los arquitectos ..., op. cit., p. 42-47. Y. SPAIRANI-BERRIO, op. cit., p. 105. Esta última ha demostrado que se conserva un contrafuerte de la iglesia renacentista como armazón de uno de los actuales, p. 265-275.
} 
do $^{17}$, y su última voluntad y nuevas pesquisas han clarificado su genealogía fami$\operatorname{liar}^{18}$, reseñable porque el también arquitecto Juan Fauquet y Verde fue su nieto ${ }^{19}$.

Tres días después del fallecimiento de Verde ya se citaba a Pedro Quintana como maestro mayor de la obra de santa María, de modo que debía estar muy cerca ${ }^{20}$, o quizá incluso a pie de obra. Durante los cuatro años siguientes asumió las mismas funciones y salario que su predecesor, e incluso el cargo de agrimensor ${ }^{21}$, pero no se contaba con más noticias acerca de su actividad, considerando Navarro que "fue solo el continuador material de las ideas y trazas del genovés" porque "coincidirían plenamente"22. Cañestro difiere y apunta que Quintana renovó la planta y amplió el conjunto ${ }^{23}$, lo cual parece posible a tenor de que en mayo de 1675 se solicitó permiso al ayuntamiento para comprar unas casas circundantes con el fin de perfeccionar dicha fábrica y trazar algunas calles ${ }^{24}$.

En julio de 1675, Quintana acudió como testigo al acto de concordia que celebraron el escultor Antonio Caro y los electos de la fábrica de santa María, por el cual se cancelaba definitivamente la realización del retablo mayor que se había contratado en 1667, pues su diseño respondía al presbiterio de la antigua parroquia, y una vezideado el nuevo templo "la obra de ditretaule que se avia de fer no pot venir bé

17 Solicitando ser enterrado en la capilla de san Juan de Letrán del convento mercedario de santa Lucía, vestido con el hábito de esta orden con la que tuvo estrechos vínculos. AHME, sig. SHPN 473, f. 84-86v. Su viuda cedió poderes a su hijo Joaquín Verde, de Enguera, seguramente para que se ocupase con libertad de lo heredado allí. Ante notario el 12 de septiembre de 1675, siendo testigo Pedro Quintana. AHME, sig. SHPN 475, f. 249v-250v. Dichos bienes aparecen referidos en un inventario de mayo de 1674, en el que también se cifran un buen surtido de muebles y enseres domésticos. Y aunque no se hace referencia al instrumental o los enseres propios del arquitecto, que pudieron pasar a Fauquet o incluso Quintana, al menos sí sabemos que Verde contaba con pinturas, en concreto con "un apostolat ab nostre Señor" y a un "quadro de sent Miquel", no por casualidad el titular de la iglesia enguerina. AHME, sig. SHPN 473, f. 125-127v.

18 Abordada con alguna confusión en T. y M. MARTíNEZ BLASCO, La arquitectura como escenario de El Misterio de Elche, Caja de Ahorros, Alicante, 1998, p. 170-171. Revisados los archivos parroquiales de Enguera, vemos que Verde concibió con su primera mujer, Catalina Zamora, a Esteban, Catalina y Ana. En Enguera, Verde enviudó y casó con Gertrudis Pujasans —o Bujasons - el 9 de abril de 1646, siendo testigos Ginés Irles y su mujer, Clara Marco. De este segundo matrimonio obtuvo una numerosa descendencia, entre ellos su homónimo. Archivo Diocesano de Valencia [ADV], Fondos del Archivo Parroquial de Enguera, sig. 372, s/f; sig. 358, s/f.

19 Ana Verde Zamora, "natural de la villa de Elche", casó el 17 de abril de 1652 con Pedro Lledosa, "lencero, de nación francés". Su hija Catalina Lledosa nació en febrero de 1653. Ana se volvió a casar en enero de 1654 con Juan Fauquet, otro lencero galo. Actuó como testigo del enlace Miguel Cantó, seguramente un cantero del que hablamos más adelante, del círculo de Pedro Quintana. En febrero de 1655 nació "Juan Pedro" Fauquet y Verde. ADV, Fondos del Archivo Parroquial de Enguera, sig. 358, s/f.

20 R. NAVARRO MALLEBRERA, Los arquitectos..., op. cit., p. 47, le sitúa en las obras del Socorro de Aspe.

21 Lo solicitó en junio. AHME, sig. a 50, s/f.

22 R. NAVARRO MALLEBRERA, Los arquitectos..., op. cit., p. 47-49.

23 A. CAÑESTRO DONOSO, Arquitectura y programas artísticos en la provincia de Alicante durante la Edad Moderna, CSIC, Madrid, 2015, p. 190.

24 AHME, sig. a 50, s/f. V. GOZÁLVEZ PÉREZ, La ciudad de Elche: estudio geográfico, Facultad de Filosofía y Letras, Valencia, 1976, p. 64. La adquisición de dichas casas, situadas en el lado norte — del Evangelio-, tuvo lugar el 2 de julio. AHME, sig. SHPN 194, f. 17-22. En este complejo proceso actuó como tasador Ginés Irles. 
en la capella major que se a de fer", cuya construcción podría demorarse "per méstemps de trenta anys" ${ }^{25}$. La presencia de Quintana en esta ocasión fue importante, pues estas precisiones temporales pudieron ser hechas por él mismo, consciente del tiempo que podía ocupar la construcción de un templo de estas características.

Hasta el momento permanecía inédito un importante dato sobre la obra de santa María: el 8 de junio de 1677 el cabildo municipal decidía paralizarla y que "des de lo dia de huinocórrega lo salaridelmestre de aquella nidemésofficials", a causa de unapesteque azotó la ciudad durante más de un año, y que provocó que las rentas municipales que se destinaban a la obra se dedicaran a la atención de $\operatorname{los}_{\text {enfermos }}{ }^{26}$. Las obras quedaban detenidas sin concluirse ni cerrarse el cuerpo de naves, y este hecho provocaría la diáspora del equipo de canteros y albañiles que conformaban la cuadrilla del maestro, lo cual repercutiría en la difusión de las maneras arquitectónicas características de esta obra. Ahora podemos desvelar algunos de los nombres de aquellos oficiales gracias a nuevas noticias.

Una de ellas apunta a la villa donde había residido Francisco Verde, Enguera, pues Quintana se obligaba a pagar una deuda de más de setenta libras que tenía contraída con un vecino de aquella; fue testigo el cantero Irles ${ }^{27}$. Junto a este había testificado en otro momento anterior el "pedrapiquer" Miguel Cantó28. Quintana asimismo constituyó en procuradores suyos a un vecino de Ontinyent ${ }^{29}$, donde había trabajado en las obras del embalse ${ }^{30}$; y antoni Térboles, como veremos cantero de su círculo, ocasión esta en que actuó como testigo Juan Fauquet ${ }^{31}$.

Rafael Soler, "mestre de canteria", cedía poderes a un notario ilicitano tras la muerte de Quintana ${ }^{32}$, con quien ya había trabajado en la elevación de la presa onte-

\footnotetext{
25 AHME, sig. SHPN 194, f. 25-29v.

26 AHME, sig. a 53, s/f. En septiembre de 1678 todavía se tomaban medidas para frenar el contagio desde ciudades afectadas como Orihuela y Murcia. AHME, sig. b 19, s/f.

27 Irles trabajaría con Quintana, al igual que había hecho con Verde, en las obras de santa María. Dicha obligación fue dada a José Benedito el 17 de junio de 1676. AHME, sig. SHPN 147, f. 152-152v.

28 Posiblemente el mismo que, en 1646 y 1654, acudió a las bodas de Verde y de su hija Ana. AHME, sig. SHPN 474, f. $249 \mathrm{v}$.

29 A Pere Morell, en 11 de enero de 1676. AHME, sig. SHPN 147, f. $7 \mathrm{v}$.

30 J. CASEY, "Irrigació i economía al País Valencià", en Primer Congreso de Historia del Pais Valenciano (Valencia, 14-18 abril 1971), Universidad de Valencia, Valencia, 1976, p. 285.

31 En 18 de julio de 1676. AHME, sig. SHPN 147, f. 167-167v.

32 El 21 de julio de 1678, a Vicent Anton de Joseph. AHME, sig. SHPN 328, f. 35v-36.
} 
niense ${ }^{33}$. A partir de entonces pudo ocuparse en la conclusión de esta, así como revisó como "mestre arquitecto de la vila de Ontiñent" junto a Julià Guillem ("mestre arquitecto de la ciutat d'Alacant') la conclusión de la de Petrer, hacia $1680^{34}$.

En la misma línea, la documentación confirma la colaboración con Quintana del desconocido Jaume Tellet, "official de canteria" y "de nació francés". La presencia de canteros y arquitectos franceses en el territorio aragonés es conocida para el episodio quinientista ${ }^{35}$, ampliándose hacia la costa y el sur y tomando especial relevancia en el tránsito del siglo XVI al XVII en el ámbito castellonense, de la mano de artífices como Joan de Ambuesa o Joan Tell o Tellet. Este trazó hacia 1605 el templo de Vistabella ${ }^{36}$, y con anterioridad un homónimo — con seguridad su padre — había asumido (ca. 1556) la obra de la basílica de santa María de Graus (Huesca) ${ }^{37}$, a su vez comenzada por el cantero Jacques de Anduxes o de Pomar. El desplazamiento de este hacia Betxí (Castellón), Valencia y posiblemente hasta Orihuela - donde se ocuparía junto con otros franceses en las obras renacentistas del colegio de santoDomingoilustra el camino que siguieron muchos de estos maestros ${ }^{38}$.

Desconocemos si nuestro Jaume Tellet estuvo emparentado con esos Tell o Tellet y es arriesgado trazar una hipótesis al respecto, por la distancia temporal que les separa y porque Jaume había resuelto volver a Francia, algo poco común entre estos artífices y que tampoco tendría mucho sentido en caso de pertenecer a una tercera

\footnotetext{
33 A. LÓPEZ GÓMEZ, op. cit., p. 118. Quizá emparentado con Vicente Soler, maestro de obras alicantino que trazó su ayuntamiento, y que en 1702 acudió a Murcia junto con Juan Blas Aparicio para valorar los proyectos presentados para el puente de piedra. J. SAÉZ VIDAL, El arte barroco en Alicante, 1691-1790, Instituto Juan Gil-Albert, Alicante, 1985, pp. 215-218. C. PEÑA VELASCO, "Religiosos arquitectos y matemáticos en las primeras décadas del siglo XVIII en Murcia”, Imafronte, n. ${ }^{\circ} 12-15,1998$, pp. 250-251. De la misma autora, El puente viejo de Murcia, Universidad de Murcia, Murcia, 2001, pp. 54-85.

34 T.V. PÉREZ MEDINA, "Agua para los regadíos meridionales valencianos: las presas del siglo XVII de Elx, Petrer y Elda", Revista de historia moderna: anales de la Universidad de Alicante, n. ${ }^{\circ} 16,1997$, pp. 279-280.

35 Véase J. IBÁÑEZ FERNÁNDEZ, "Renacimiento a la francesa en el Quinientos aragonés", Artigrama, n. ${ }^{\circ} 22$, 2007, pp. 473-512.

36 Y. GIL SAURA y A. ZARAGOZÁ CATALÁN, "Obradores y talleres en el Maestrazgo de Montesa. Siglos XIII-XVIII", en Pulchra Magistri: l'esplendor del Maestrat a Castelló, catálogo de la exposición (Castellón, 2013-2014), Yolanda Gil (com.), 2013, p. 37.

37 C. PERRELA LARROSA, "El piedrapiquero Joan Tellet, una aproximación a su obra y su personalidad artística”, en Actas del V Coloquio de Arte Aragonés, Diputación General de Aragón, Zaragoza, 1989, pp. 479-496.

38 M. GÓMEZ-FERRER, "El palacio renacentista de Betxí (Castellón). Aportaciones a su historia constructiva", Artigrama, n. ${ }^{\circ}$ 29, 2014, pp. 305-337, identificó a Jacques de Anduxes con el Jacques de Pomar que interviene en Betxí. La noticia sobre maestros franceses en Orihuela, en J. GARCÍA SORIANO, El colegio de Predicadores y la Universidad de Orihuela, Domingo L. Riquelme, Orihuela, 1918, p. 69-71.
} 
generación de migrantes ${ }^{39}$. El regreso tuvo lugar en marzo de 1678, otorgando poderes al referido Térboles, también oficial de cantería, seguramente para que cobrase la deuda que con él tenía pendiente Quintana, y que según un albarán había ascendido a 49 libras $^{40}$. En el momento de la partida, no obstante, restaban solo diez reales de deuda, lo cual confirmaron "Armendia, Antoni Térboles, Miquel Balda ${ }^{41}$ y Juan [Fauquet] Verde". De estos no se mencionan más datos, pero podemos suponerles ocupados en la misma cuadrilla; además, la futura coincidencia de Fauquet con Martín de Armendia, maestro de obras de origen navarro instalado en Almansa (Albacete) hacia 1704,podría ayudarnos a identificar con él al nombrado en este documento.

La estancia de un oficial francés junto a Quintana y en este entorno, si es que no hubo más ${ }^{42}$, plantea interesantes reflexiones. La puesta en práctica de la tradición estereotómica francesa se consideraba en este momento "fruto y consecuencia de la nueva geometría descriptiva y de la especulación aritmético-matemática" ${ }^{43}$.La tradición hispana no era ajena a ello, y muchísimo menos la mediterránea; no por casualidad, hasta el estallido de la guerra de las Germanías (1519-1523) la construcción valenciana, nutrida también por la presencia de canteros vasconavarros ${ }^{44}$, había alcanzado una notable perfección en el corte de la piedra, "que conllevó, a su vez, un mayor conocimiento de la geometría del espacio". Y aunque tras la guerra la cantería perdió relevancia en el ámbito de la ciudad de Valencia, en el meridional obispado de Cartagena vivió un importante episodio con la montea renacentista de Quijano en Orihuela $^{45}$, villa apenas alejada de Alicante — donde fue objeto de actualización con la elevación de su colegial—y aún menos de esta de Elche.

39 M. GÓMEZ-FERRER y A. ZARAGOZÁ CATALÁN, "Lenguajes, fábricas y oficios en la arquitectura valenciana del tránsito entre la Edad Media y la Edad Moderna (1450-1550)”, Artigrama, n. 2 23, 2008, pp. 149-184, comentan lo poco frecuente del caso de Benet Augier, que trabajó a comienzos del siglo XVI en Reus y Ontinyent para luego regresar a Francia.

40 AHME, sig. SHPN 328, f. 16v-18.

41 Miquel Balda o Belda fue un activo parroquiano de santa María, oincidiendo casi siempre con Juan Fauquet. J. CASTAÑO GARCÍA, Llibre de la fàbrica ..., op. cit.

42 Aun sin relación aparente, en 1679 se adjudicaron las obras del embalse de Petrer (Alicante), trazado por Joaquín Bernabéu, a otro francés: Miguel Raymundo. A. LÓPEZ GÓMEZ, op. cit., p. 118.

43 A. RODRÍGUEZ GUTIÉRREZ DE CEBALlOS, "Prólogo", en J. BÉRCHEZ, Arquitectura barroca ..., op. cit., p. 18.

44 M. FALOMIR FAUS, Arte en Valencia. 1472-1522, Consell Valencià de Cultura, Valencia, 1996, p. 150.

45 J. BÉRCHEZ, Arquitectura renacentista valenciana, Bancaja, Valencia, 1994, pp. 64-81. M. GÓMEZ-FERRER y A. ZARAGOZÁ CATALÁN, op. cit., pp. 180-182. 
Es preciso pues juzgar correctamente la coincidencia de canteros autóctonos, aragoneses, navarros y franceses ${ }^{46}, \mathrm{y}$ con ello destacar que, en un momento en que se popularizaban otras técnicas constructivas de distinta complejidad, la colaboración de artífices de diversa procedencia y formación daría lugar en estos lares a cuadrillas muy preparadas técnicamente para la pervivencia y renovación de la tradición estereotómica.

Quintana sobrevivió apenas cuatro años a Francisco Verde y murió el 18 de junio de 1678, habiendo testado solo dos días antes por sufrir "greu malaltia corporal de la qual tem morir" ${ }^{\text {" } 77}$, quizá provocada por uno de los brotes de peste que forzaron la paralización de la obra. Se sucedió entonces un periodo sin arquitecto director, que se ha atribuido a "circunstancias dependientes del propio planteamiento constructivo", en el que los electos de la fábrica habrían aprovechado la muerte del maestro para detener el desarrollo edilicio y centrarse en lo ornamental, dada la posibilidad extraordinaria de contratar al escultor estrasburgués Nicolás de Bussy ${ }^{48}$.

Debe aclararse, no obstante, que la ausencia de un maestro que dirigiera las obras en este periodo es consecuencia de su referida suspensión a partir de junio de 1677, y no de la muerte de Quintana, que se produjo al año siguiente. Si la fábrica se centró en lo ornamental después de este lapso indeterminado, aun sin estar concluidas las naves, debió ser porque las rentas todavía no permitían su reanudación total, pues la fábrica tuvo diversos problemas de financiación.

\footnotetext{
46 Sobre las interpretaciones de la arquitectura y cantería españolas como trasunto de lo francés, véase F. MARÍAS, "Cuando El Escorial era francés: problemas de interpretación y apropiación de la arquitectura española", Anuario del Departamento de Historia y Teoría del Arte, n. ${ }^{\circ}$ 17, 2005, pp. 21-32.

47 Dispuso ser enterrado, como Verde, en la capilla de san Juan de Letrán del convento de santa Lucía, con el hábito mercedario. AHME, sig. SHPN 149, f. 116v-120v.

48 R. NAVARRO MALLEBRERA, Los arquitectos..., op. cit. p. 51. Bussy es una de las figuras más enigmáticas del barroco español. Originario de Estrasburgo, hacia 1659 llegó a la Corte con el séquito de Juan José de Austria, quizá con el objetivo de ocuparse en la culminación de la fachada del Alcázar. R. ALONSO MORAL, "Nicolás de Bussy, escultor del rey. Su etapa en el Palacio de Aranjuez", en Nicolás de Bussy: un escultor europeo en España, Real Academia de Bellas Artes, Murcia, 2006, pp. 33-53. En 1662 pasó a Valencia, donde se empleó como ofícial en el taller de Tomás Sanchis, dadas las restricciones gremiales, y en 1668 adquirió la maestría. A.M. BUCHÓN CUEVAS y M.J. LÓPEZ AZORÍN, "Escultores extranjeros maestros del gremio de carpinteros de Valencia. Nicolás de Bussy, Julio Capuz y Francisco Stolf”, Boletín de la Sociedad Castellonense de Cultura, n. ${ }^{\circ}$ 76, 2000, pp. 161-168. Hacia 1673 pasó a Alicante, donde permaneció hasta al menos 1684, yendo después a Murcia. L. HERNÁNDEZ GUARDIOLA, "Bussy y sus colegas en Alicante", en Nicolás de Bussy: un escultor europeo en España, Real Academia de Bellas Artes, Murcia, 2006, pp. 73-82.
} 


\section{El proyecto original en la arquitectura seiscentista}

Verde realizó el proyecto inicial con el que arrancaron las obras, si bien, como se ha indicado, este pudo recibir modificaciones posteriores por parte de Quintana. Una reflexión detenida acerca de la obra y trayectoria de ambos contribuye a una mejor comprensión de los planos originales en las coordenadas que delimitaban la arquitectura del momento.

En primer lugar, la construcción destaca por el carácter monumental de sus proporciones, que distan de las habituales para una parroquia. Efectivamente, era la más grande de las ilicitanas, pero también el hogar de la patrona de la ciudad y, quizá por encima de todo, el escenario del Misteri, drama sacro de tradición inmemorial y que condicionó la vida de la comunidad ilicitana. Estos factores, sumados a una cierta competencia o emulación respecto a Alicante, explican la deuda de este templo con el de la colegiata de san Nicolás de la ciudad portuaria.

Esta iglesia de san Nicolás, iniciada entre 1613 y 1616 por Agustín Bernardino y continuada después por su discípulo Martín de Unceta, se convirtió en referente para el desarrollo de la arquitectura seiscentista de la zona por sus valores tectónicos, alarde canteril y perfectas proporciones geométricas (Fig. 2). Muy presente hubo de tenerla Verde en la primera de sus obras conocidas, la mencionada iglesia de san Miguel de Enguera, concluida en $1645^{49}$. Con ella asumiría un proyecto ya iniciado, pues fue una de las parroquias que el arzobispo Juan de Ribera mandó reconstruir hacia 1585, dilatándose su ejecución ${ }^{50}$. Además, en marzo de 1748 sufrió los efectos del terremoto de Montesa, cayendo parte de la torre y las bóvedas ${ }^{51}$, de modo que no es fácil dirimir cuánto de ella puede atribuirse a nuestro arquitecto y a su momento

\footnotetext{
49 M.J. LÓPEZ AZORÍN, "El claustro...”, op. cit., p. 214.

50 El proceso constructivo resulta enigmático. En 1592 se convinieron obras con el cantero Pedro Garcerán. En 1613 se pagaron 29 libras a Joaquín Bernabéu y Jordà Silva, "obrers de vila”, por inspeccionar la obra hecha y hacer nuevas trazas. F. ALMELA Y VIVES, "San Juan de Ribera y el templo parroquial de San Miguel de Enguera”, en Aproximación a la historia de Enguera, Ayuntamiento de Enguera, Enguera, pp. 189-193. Más revelador resulta el estudio de J.M. JIMÉNEZ PIQUERAS, "La antigua iglesia parroquial", en Historia de Enguera. Nuevas aportaciones (1994-2014), Ayuntamiento de Enguera, Enguera, 2014, pp. 101-110. Estos estudios, basados en referencias del erudito Pedro Sucías, limitan la intervención de Verde a la supervisión final de las obras, en 1645.

$51 \quad$ N. BAS MARÍN (et. al), El archivo parroquial de san Miguel de Enguera, Facultad de Teología de san Vicente Ferrer, Valencia, 2001, p. 21.
} 


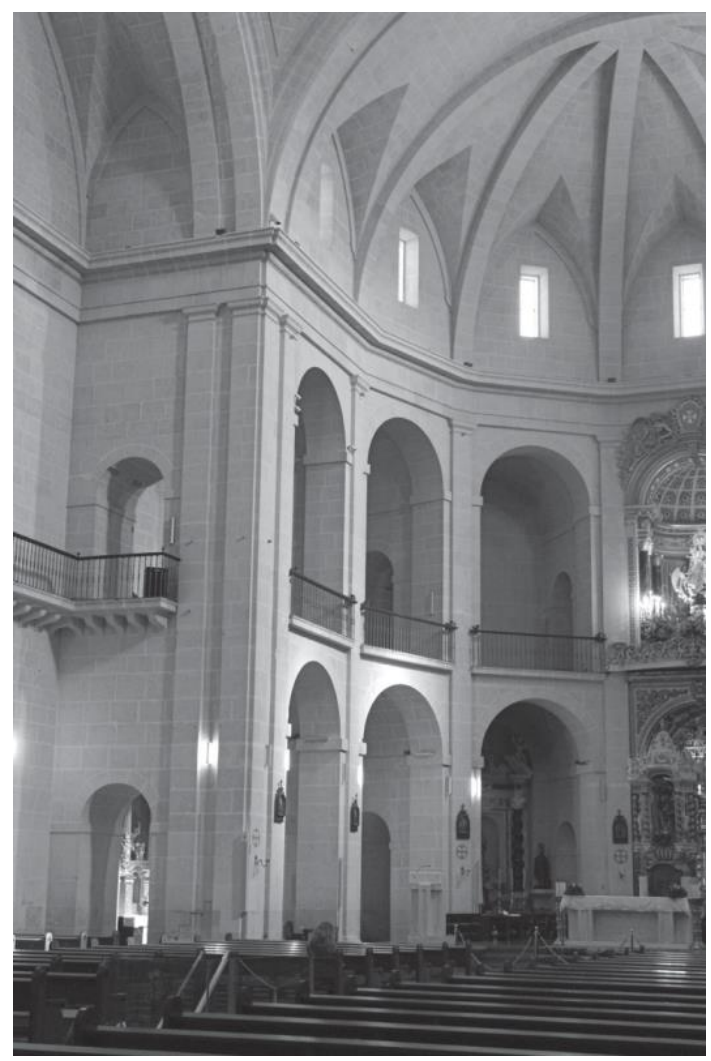

Fig. 2. Iglesia de san Nicolás, de Alicante (Foto del autor).

histórico. De cabecera poligonal y cubierto con crucerías, demuestra dicción clasicista en la ordenación de las naves y en la original portada principal, que se inserta en un paramento liso de piedra, por lo cual fue definida como "de estilo tardorrenacentista herreriano" $" 52$.

De esta de San Miguel de Enguera interesa, sobre todo, que dicho imafronte se remata con un hastial mixtilíneo con bolas y pináculos, que sigue el modelo que Bernardino desarrolló en San Nicolás, y que había ensayado previamente en el crucero de la iglesia de las santas Justa y Rufina (Orihuela). Al igual que en la de Enguera,

52 F. M. GARÍN ORTIZ DE TARANCO, Catálogo monumental de la provincia de Valencia, Caja de Ahorros, Valencia, 1986, pp. 247-251. 

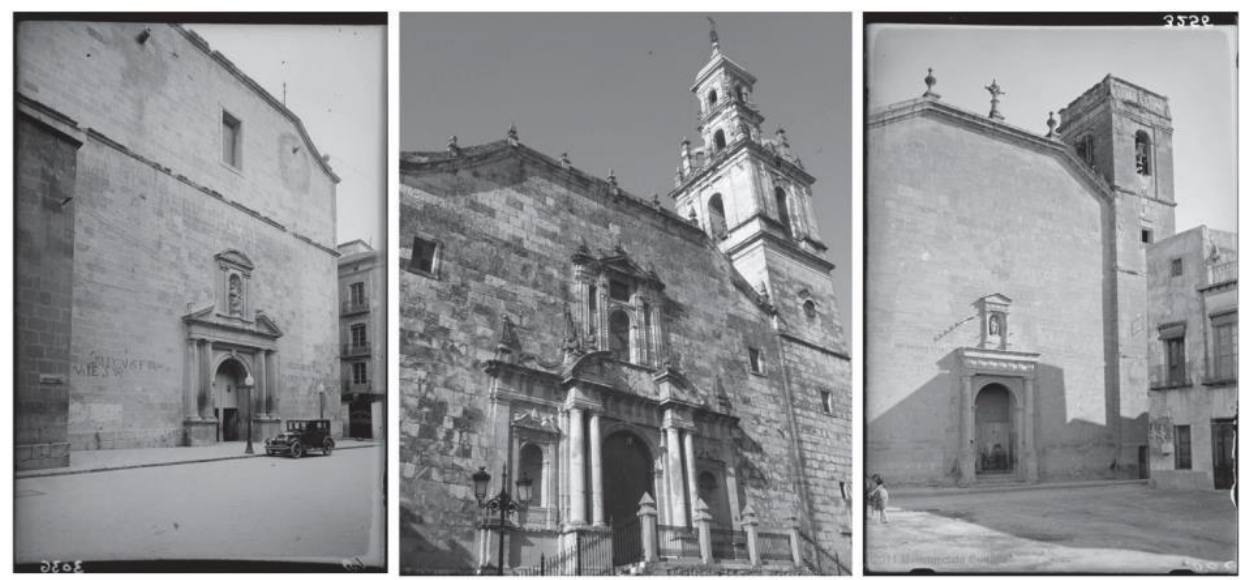

Fig. 3. De izquierda a derecha: iglesia de san Nicolás, de Alicante (Foto: A. Passaporte. A. Loty, IPCE, MCU); iglesia de san Miguel, de Enguera (Foto: Nacho Vila); e iglesia de san Juan Bautista, de Elche (Foto: A. Passaporte. A. Loty, IPCE, MCU).

dicho hastial tuvo réplicas en otras como la del Salvador, de Elche (destruida) ${ }^{53}$. El remate de perfiles rectos de la también ilicitana de San Juan Bautista (destruida)

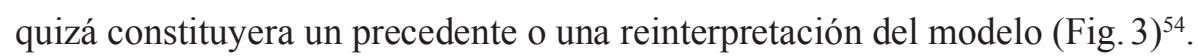

No obstante, la novedad de la fachada de Verde para Enguera se encuentra en el remate corrido que la corona y que subraya su cierre oblicuo, una fórmula que retomaría con posterioridad el arquitecto Juan Blas Aparicio en la iglesia de Santa María de Cocentaina $(1691)^{55}$, acentuando sus perfiles y renovando este tipo de "cornisa recta y obliqua", que a partir de entonces y a lo largo del XVIII vivió evolución y éxito en toda la geografía del Reino valenciano, y que Aparicio pudo conocer de primera mano en la obra de Verde dado el origen enguerino que se le ha venido atribuyendo - en el que insistiremos más adelante-.

\footnotetext{
53 Atribuida a algún discípulo de Bernardino. A. CAÑESTRO DONOSO, Gloria pretérita. La parroquia del Salvador de Elche, A. Cañestro, Alicante, 2011, pp.41-43.

54 Su proceso constructivo sigue siendo desconocido, pudiendo fijarse su comienzo a finales del XVI. A. CAÑESTRO DONOSO, "Algunas notas sobre la iglesia de San Juan Bautista de Elche, sus fábricas y ajuares", Carthaginensia, n. $^{\circ}$ 30, 2014, pp. 193-219.

55 Sobre la obra contestana, véase F. JOVER, "Engrandiment de l'esglèsia i construcció del campanar de Santa María de Cocentaina", Alberri: Quaderns d'investigació del centre d'estudis contestants, n. ${ }^{\circ}$ 10, 1997, pp. 111-190. P. GONZÁLEZ TORNEL, Arte y arquitectura en la Valencia de 1700, Alfons el Magnànim, Valencia, 2005, pp. 81-84.
} 
En relación con el encargo de la iglesia enguerina de san Miguel, promovido por el padre mercedario Tomás Ramos, está la posterior intervención de Verde en el monasterio también mercedario del Puig (Valencia), bajo los auspicios de José Sanchis, padre provincial (1659-1664) y después general (1664-1672) que le calificó como un "grande arquitecto" 56 . Allí trabajó estrechamente con Juan Pérez Castiel en la realización de las galerías oeste y sur del patio, alrededor de $1667^{57}$, quedando como arquitecto supervisor y de referencia para la construcción de la galería norte en 1670 , lo cual podría indicar que fue el tracista del conjunto del claustro ${ }^{58}$. Sobre este se ha apuntado que "construido en ladrillo perfectamente aparejado, ofrece un noble diseño", con una ingeniosa solución que finge dos pisos para la segunda crujía, estando sus pilastras dobladas en altura respecto a las inferiores y rematadas por unos capiteles vistos también en la fachada de la basílica de los Desamparados ${ }^{59}$. Bérchez advirtió que estos capiteles respondían en realidad a una variación del conocido como orden "del hermano Bautista", en boga por entonces en la corte, y señalaba que posteriormente Verde lo había desarrollado en los apilastrados de santa María de Elche ${ }^{60}$.

Conocido el importante alcance de la intervención de Verde en el Puig, cobran nuevo sentido todas estas relaciones, que confirman en él versatilidad, gran cultura arquitectónica y un papel destacado en la difusión de las formas delmomento, amén de un prestigioso criterio. No en vano, acudió a Valencia reclamado como experto en diferentes ocasiones, como en 1653, para la visura de las primeras obras de la nueva capilla de la Virgen de los Desamparados, dirigidas por Diego Martínez Ponce de Urrana ${ }^{61}$; o en 1660 para dar cuenta de la reparación de uno de los pilares sustentantes del cimborrio de la catedral ${ }^{62}$.

\footnotetext{
56 M.J. LÓPEZ AZORÍN, "El claustro...”, op. cit., p. 214.

57 F. GARÍN ORTIZ DE TARANCO, op. cit., pp. 426-432. J. BÉRCHEZ, Arquitectura barroca ..., op. cit., p. 38.

58 M.J. LÓPEZ AZORÍN, "El claustro...", op. cit., p. 215.

59 F. BENITO DOMÉNECH, "Real monasterio de santa María. El Puig", en Catálogo de monumentos y conjuntos de la Comunidad Valenciana, J. BÉRCHEZ (coord.), Conselleria de Cultura, Valencia, 1983, pp. 54-64.

60 J. BÉRCHEZ, Arquitectura y academicismo, Alfons el Magnànim, Valencia, 1987, pp. 165-166. Su utilización en estos tres conjuntos concretos evidenciaría la "vinculación modal" de este orden con la significación mariana, algo adelantado por F. MARÍAS, "Orden y modo en la arquitectura española", en Dórico, jónico corintio en la arquitectura del Renacimiento, E. FORSSMAN, Xarait, Madrid, 1993, p. 32.

61 J. RODRIGO PERTEGÁS, Historia de la antigua y Real Cofradia de Nuestra Señora de los Inocentes, Hijos de F. Vives, Valencia, 1922, p. 318.

62 J. SANCHIS SIVERA, La catedral de Valencia, F. Vives, Valencia, 1909, p. 197. Y. GIL SAURA, "La iglesia de la Purísima Concepción Victoria de Tortosa, el arquitecto Juan Ibáñez y la arquitectura valenciana del seiscientos", Nous col-loquis, n. ${ }^{\circ} \mathrm{IV}, 2000$, pp. 181.
} 


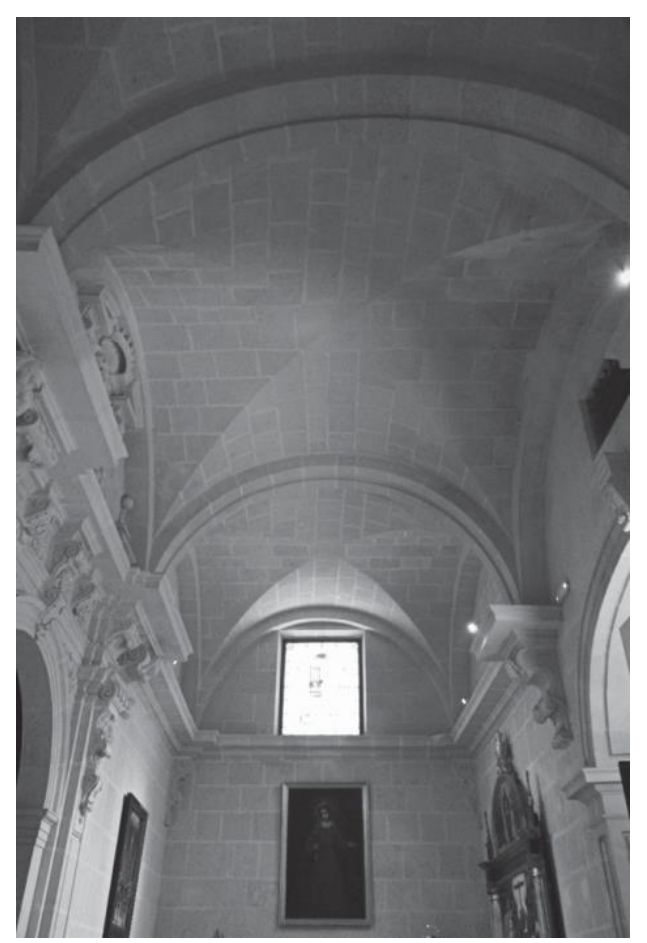

Fig. 4. Sacristía de la iglesia de San Nicolás, de Alicante (Foto del autor).

Regresando al referente de la colegial de san Nicolás de Alicante, en ella había intervenido Quintana entre 1660 y 1662, dirigiendo las obras de su sacristía ${ }^{63}$. Resuelta en un notable trabajo de cantería y de acentuado geometrismo en su concepción, se cubre con bóvedas de arista, mientras que los arcos descansan sobre salientes cornisas, a su vez apoyadas sobre unas ménsulas de geométricos perfiles con hojarascas decorativas (Fig. 4) ${ }^{64}$. El valor dado a la piedra y los principios estereotómicos del conjunto conectan perfectamente no solo con el proyecto original de Bernardino, sino también con la estela de la obra oriolana y murciana del escultor y arquitecto

63 Noticia rescatada por Martínez Morellá, recogida en R. NAVARRO MALLEBRERA, Los arquitectos..., op. cit., p. 37. También se ha afirmado que intervino en las obras de la torre. I. VIDAL BERNABÉ y R. NAVARRO MALLEBRERA, "San Nicolás. Alicante", en Catálogo de monumentos y conjuntos de la Comunidad Valenciana, J. BÉRCHEZ (coord.), Conselleria de Cultura, Valencia, 1983, p. 97.

64 Similar concepción se advierte en la construcción de la Casa Consistorial de Castalla, levantada por parte de Quintana hacia 1664, (P. MADOZ, Diccionario geográfico-estadístico-historico de España y sus posesiones de ultramar, P. Madoz y L. Sagasti, Madrid, 1846-1850, vol. 6, p. 76. E. TORMO Y MONZÓ, op. cit., p. 250), en piedra bien trabajada y trazada atendiendo a la simetría y geometrización de todo el conjunto y de sus diferentes elementos, como el alfiz que encierra a los arcos de la galería inferior. 


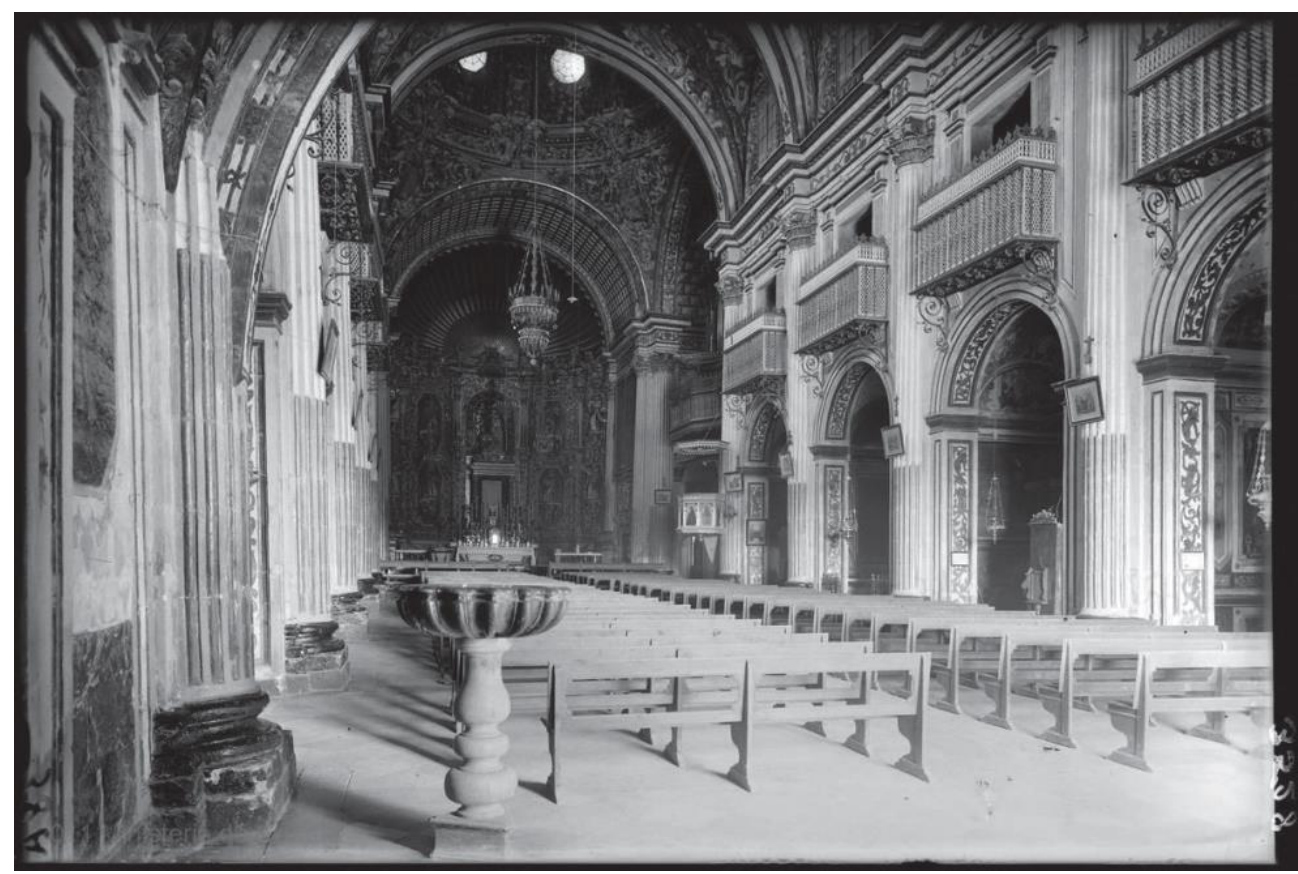

Fig. 5. Iglesia del colegio de santo Domingo, de Orihuela (Foto: A. Passaporte. A. Loty, IPCE, MCU).

renacentista Jerónimo Quijano (†1563), que "no solo se prolongó en sus discípulos durante toda la segunda mitad del siglo [XVI], también alcanzó a los arquitectos de finales del siglo XVII" 65 .

En este sentido, Quintana tuvo la oportunidad de estudiar y reinterpretar el lenguaje de Quijano de primera mano, pues en 1659 realizó las trazas para la reconstrucción de la iglesia del colegio de santo Domingo de Orihuela, diseñada en 1553 por aquel maestro y levantada antes de 1593 por Juan Inglés. Parte importante de este templo se arruinó entre 1654 y 1658, si bien se conservó el singular presbiterio poligonal, cubierto por la sucesión de una bóveda de cañón casetonada y por otra de horno avenerada ${ }^{66}$. Quintana hubo de idear así un nuevo cuerpo de naves, cuyas

\footnotetext{
65 J. BÉRCHEZ, Arquitectura barroca ..., op. cit., p. 64.

66 F. MARÍAS Y A. BUSTAMANTE, "Don Fernando de Loaces y el Colegio de Santo Domingo de Orihuela", en Patronos, promotores, mecenas y clientes: VII congreso del CEHA (Murcia, 1998), Universidad de Murcia, Murcia, 1992, pp. 212-215. Sobre el conjunto de santo Domingo, véase J.A. MACIÁ RUIZ, Arquitecturas en el colegio diocesano de Santo Domingo de Orihuela (1553-1737) (Tesis doctoral), Universidad de Alicante, 2013.
} 
divergencias con el previo — nave única de seis tramos, bóvedas de crucería, capillas laterales sin comunicar, ausencia de crucero - demuestran el siglo transcurrido y la evolución de la sensibilidad arquitectónica. Así, incluyó en su proyecto un crucero, sin destacarlo en planta, coronado por una cúpula que al exterior se traduce en un cubo cubierto a cuatro aguas, algo poco frecuente en este ámbito geográfico. Buscando otorgar mayor funcionalidad al espacio del templo, las capillas se conectaron entre sí al perforar los contrafuertes, creando espacios de paso que actuaban como naves laterales.

Pero el mayor interés de esta intervención en santo Domingo de Orihuela reside en el alzado de la nave, tanto por ordenarse con medias columnas corintias de orden gigante, buscando la unidad con el presbiterio renacentista; como, sobre todo, por la presencia de una galería sobre las capillas laterales ${ }^{67}$. Tras la renovación del uso de estas galerías efectuada en san Nicolás de Alicante, Quintana fue más allá en cuanto a dinamismo, al abrirlas a la nave a través de vanos angulares - y no arcosdispuestos sobre los arcos de las capillas, sin la presencia de entablamento o cornisa que divida los pisos (Fig. 5). Este alzado se nos antoja estrechamente vinculado a la solución ofrecida por Diego Martínez Ponce de Urrana en la referida basílica valenciana de los Desamparados, comenzada hacia 1652, y cuyo proyecto Quintana pudo conocer a través de Verde.

Con todo, la traza de las naves de la parroquia de santa María de Elche es deudora de la colegiata de san Nicolás de Alicante, tanto en su carácter monumental y en la pretendida exhibición de las calidades de la piedra, como en la existencia de una tribuna sobre las capillas laterales y de una girola, también con galería superior; no obstante, difiere en importantes aspectos, derivados de la experimentación arquitectónica puesta en práctica en otras destacadas empresas edilicias. Primero, en la introducción de claroscuros, placas y mol- duras decorativas, aunque sea con un sentido ornamental muy atemperado. Segundo, y en relación con lo anterior, en el uso del orden "del hermano Bautista", menos austero, más dinámico y con mayor carga simbólica por su vinculación al culto mariano, del que este templo es magnífico estandarte. Y, finalmente, se distingue por la combinación de arcos y vanos adintelados entre las

\footnotetext{
67 La ejecución material del templo dominico cayó en manos de Alberto Mendieta a partir de julio de 1660 . Verde visuró las obras en 1664, pero las valoró negativamente, lo cual llevó al Colegio a sustituir a Mendieta por Jusepe Martínez, que las concluyó en 1690 (J. GARCÍA SORIANO, op, cit., pp. 68-72), y con quien volvería a coincidir Quintana en marzo de 1676, en la supervisión que hicieron de las obras de la oriolana iglesia del Carmen. (D. GARCÍA HINAREJOS, "El convento del Carmen de Orihuela y los informes y juicios para la reparación de los defectos de fábrica de su iglesia”, en Los clasicismos en el arte español: X congreso del CEHA, UNED, Madrid, 1994, pp. 507-514). En el siglo XVIII la iglesia fue completamente redecorada y todas sus superficies policromadas.
} 
capillas y la tribuna, reseñada como rasgo original e innovador ${ }^{68}$, pero que en realidad había sido introducida ya en otro templo de importante significación mariana (Desamparados), trasladándose al sur con la intervención de Quintana en Orihuela.

Dicho todo esto, no podemos dirimir si las naves del edificio actual son reflejo preciso de las trazas originales de Verde; o si fue Quintana quien introdujo sus modificaciones una vez se hizo cargo de las obras, como podría apuntar alguna de las noticias documentales que hemos aportado. Tampoco puede olvidarse la estrecha relación que debió existir entre ambos arquitectos, y su repetida coincidencia ha llevado a afirmar que existió un vínculo de colaboración, e incluso de discipulado Verde-Quintana ${ }^{69}$. Este discipulado se ha apuntalado sobre la supuesta sucesión de uno y otro al frente de la iglesia del Socorro de Aspe (Alicante), que se ha planteado como un preludio de lo ocurrido en Elche ${ }^{70}$. Y aunque existen dudas sobre la obra de Aspe $^{71}$, no se invalida la relación que entre ellos venimos documentando ${ }^{72}$. Eso sí, dado que tendrían una edad semejante, pero orígenes y formaciones diversos, sus paralelismos apuntan más bien a una sensibilidad arquitectónica recíprocamente nutrida, así como a un compartido círculo de colaboradores y oficiales.

Unos años después de la muerte de Quintana, encontramos trabajando en santa María de Elche a Nicolás de Bussy, en un vínculo que en realidad no era

68 Así lo creía R. NAVARRO MALLEBRERA, Los arquitectos..., op. cit., pp. 44-45. R. NAVARRO MALLEBRERA e I. VIDAL BERNABÉ, "Arte”, en Historia de la provincia de Alicante. Edad Moderna, A. MESTRE (dir.), Ediciones Mediterráneo, Murcia, 1985, pp. 450-452.

69 R. NAVARRO MALLEBRERA, Los arquitectos ..., op. cit., p. 47. A. CAÑESTRO DONOSO, Arquitectura y programas artísticos..., op. cit., p. 190.

70 Se ha dicho que Verde la trazó y comenzó hacia 1650-1652, siendo sucedido por Quintana entre 1660-1662. R. NAVARRO MALLEBRERA, "Anotaciones sobre la historia de la construcción de la iglesia parroquial de Aspe", $L a$ Serranica, s/n, 1980; y NAVARRO MALLEBRERA e I. VIDAL BERNABÉ, “Arte”, op. cit., p. 450, se basan en M. CREMADES, Aspe, Novelda y Monforte, Alicante, 1966 y en G. VIDAL TUR, Un obispado español: el de Orihuela-Alicante, Gutenberg, Alicante, 1962, vol. II, p. 505, que de manera confusa advierte que "es una magnífica construcción del arquitecto Francisco Verde, por 1676"; datación que resulta imposible por su muerte en 1674.

71 M.C. PÉREZ CREMADES y J. PRIETO ALZAMORA, "Historia de la construcción de la parroquia de nuestra Señora del Socorro", en Estudios sobre la parroquia de Nuestra Señora del Socorro, Ayuntamiento, Aspe, 2004, pp. 21-28, señalan que esta teoría solo se sustenta sobre vacíos documentales en la actividad de estos artífices, y por ello la cuestionan y proponen su construcción entre 1728 y 1737 . No obstante, hay noticias que indican que Quintana tuvo algún interés en Aspe, quizá derivado de aquella obra. En Elche, el 5 de agosto de 1677, dio poderes a Juan de Mira, "de la vila de Asp" (AHME, sig. SHPN 339, f. 48-48v). Además, en el mismo documento Quintana actúa como representante de Antonio Caro, según habían acordado previamente. No podemos confirmar si se trata del escultor Caro, que trabajó en Castalla en fechas próximas a las de la realización de la casa consistorial por parte de Quintana (ca. 1660), y al que también se han atribuido trabajos en Aspe en aquellos años; de hecho, a su muerte en 1678 el escultor afirmaba tener deudores en aquella villa, como se confirma en P. SEGADO BRAVO, "El escultor-retablista Antonio Caro 'el viejo' (+1678)", Imafronte, n. ${ }^{\circ}$ 2, 1986, p. 97.

72 Ver nota 18. 
nuevo. Bussy trabajaba en el taller de Tomás Sanchis cuando este realizó las trazas para el inconcluso retablo mayor, y en 1675 fue requerido para tasar lo realizado ${ }^{73}$. Además, otro de los nexos que le unen con este templo no es otro que el propio Francisco Verde, su periplo vital — con diversas visitas a Valencia, donde trabajaba el escultor-y algunos comunes valedores ${ }^{74}$. En cualquier caso, Bussy, tras una estancia de un año en Aranjuez ${ }^{75}$, se ocupó entre 1680 y 1682 de trazar y ejecutar las portadas de san Agatángelo y la principal dedicada a la Asunción, además de las molduras y cornisas de su interior, obras donde demuestra un absoluto dominio técnico, del diseño y del tallado de la piedra, con variadas influencias italianas y centroeuropeas $^{76}$.

$\mathrm{Su}$ adición al conjunto arquitectónico abría un nuevo camino para la arquitectura pétrea frente a la severa desnudez de la iglesia de san Nicolás de Alicante. Esta alternativa optaba así por una templada y comedida expresión decorativa, que daba protagonismo a la exhibición estereotómica pero a la vez conectaba con las reformas barrocas que entonces se estaban empezando a solicitar, con culto entusiasmo, por cabildos y parroquias, como ocurrió en el presbiterio de la catedral de Valencia (proyectos de 1671 y 1675) ${ }^{77}$. A la misma actitud respondería el recubrimiento de la capilla de la cabecera de san Nicolás, con todo un nuevo dispositivo salomónico de madera tallada, dorada y policromada, realizado

\footnotetext{
73 C.E. NAVARRO-RICO, "El antiguo retablo de santa María de Elche: obra de Antonio Caro y Tomás Sanchis", Archivo de Arte Valenciano, n. ${ }^{\circ}$ 99, 2018, p. 59-73.

$74 \quad$ En 1674, Bussy talló un crucificado para la parroquial de Enguera, encargo que se ha sugerido realizado por Francisco Verde, dada su vinculación con este templo y el contacto que pudieron establecer en alguna de sus estancias en Valencia. Asimismo, agudamente se ha advertido un importante nexo de unión entre los dos artistas: el padre mercedario José Sanchis, de grandes inquietudes artísticas y arquitectónicas, al que se deben las obras del Puig realizadas por Verde y Pérez Castiel, y que actuó como valedor del escultor en diferentes ocasiones. Véase M.J. LÓPEZ AZORÍN, "El claustro...", op. cit., y de la misma autora, "Estancia y presencia de D. Nicolás de Bussy en Valencia", en Nuevas aportaciones al estudio del escultor barroco Nicolás de Bussy, Archicofradía de la Sangre, Murcia, 2005, pp. 17-30. Por último, cabe decir que Sánchez-Rojas Fenoll consideraba que la portada principal de santa María habría sido diseñada por Verde, y que Bussy habría partido de su proyecto para ejecutarla, extremo que resulta improbable. M.C. SÁNCHEZ-ROJAS FENOLL, El escultor don Nicolás de Bussy, Universidad de Murcia, Murcia, 1982, p. 43.

75 L. HERNÁNDEZ GUARDIOLA, op. cit, p. 76.

76 Sobre este asunto, véase I. VIDAL BERNABÉ, La escultura monumental barroca en la diócesis de Orihuela-Alicante, Diputación de Alicante, Alicante, 1981, p. 29-56.

77 Sobre esta reforma, véase S. ALDANA, "El arquitecto barroco Juan Pérez Castiel", Boletín de la Sociedad Castellonense de Cultura, n. ${ }^{\circ}$ 43, 1967, pp. 55-87; F. PINGARRÓN, Arquitectura religiosa del siglo XVII en la ciudad de Valencia, Ayuntamiento, Valencia, 1998, pp. 109-123; y la más reciente revisión de J. BÉRCHEZ y M. GÓMEZ-FERRER, "Vestir a lo moderno: la remodelación barroca del presbiterio de la catedral de Valencia", en M. Miglio y A.M. Oliva (coords.), Rinascimiento italiano e committenza valenzana: gli angeli musicanti della cattedrale di València, Istituto Storico Italiano per il Medio Evo, Roma, 2011, pp. 207-227.
} 
por José Villanueva entre 1675 y 1676, y cuyo diseño precisamente se ha vinculado a Bussy $^{78}$.

\section{El arquitecto Juan Fauquet}

Ya Tormo afirmaba que Juan Fauquet había proseguido la fábrica de santa María tras Verde y Quintana ${ }^{79}$. Como dijimos, nació en Enguera en 1655, siendo nieto de Verde ${ }^{80}$, y en 1676 le hemos documentado en Elche junto a Pedro Quintana, de modo que debió viajar hasta allí con su abuelo - y parte de su familia — para formarse y trabajar a su lado ${ }^{81}$.

Vinculado desde su llegada a Elche con la parroquia de santa María, a partir de diciembre de 1680 participó habitualmente en sus asambleas como un parroquiano más ${ }^{82}$. La intervención decorativa de Bussy debió espolear de nuevo la construcción, y en abril de 1681 ya aparece cobrando por ella, siendo mencionado como "mestre" a partir de marzo de 1682. Concluyó el cuerpo de naves, cerrándolo con un muro en 1686 y cubriendo las bóvedas con mampostería ${ }^{83}$, utilizándose así

78 I. VIDAL BERNABÉ, Retablos alicantinos del barroco, Universidad de Alicante, Alicante, 1990, pp. 73-75, dio a conocer su factura por parte de Villanueva, indicando influencia valenciana y también bussiana, no tanto en la ejecución sino en algunos diseños. J. SÁEZ VIDAL, "Retablo de san Nicolás", en La luz de las imágenes. La faz de la eternidad, catálogo de la exposición (Alicante, 2006-2007), Alicante, 2006, p. 306, lo relacionó con modelos derivados de la obra de Pedro de la Torre. L. HERNÁNDEZ GUARDIOLA, "Bussy y sus colegas...", op. cit., p. 74, sugiere que el conjunto fue diseñado por Bussy.

79 E. TORMO Y MONZÓ, op. cit., p. 294.

80 En una brevísima varia, López Jiménez aportó -aun sin citar las fuentes- los datos sobre su origen enguerino y sus matrimonios: casó en santa María de Elche el 1 de marzo de 1677 con María Zaragoza; y por segunda vez en 1683 con Lorenza Sánchez. J.C. LÓPEZ JIMÉNEZ, "Varia de arte”, Archivo de Arte Valenciano, n. o 31, 1960, pp. 62-63. Navarro Mallebrera aportó una declaración del arquitecto según la cual en 1686 contaba con 28 años, calculando su nacimiento en torno a 1658, aunque son conocidas las frecuentes inexactitudes del cálculo de la edad en aquella época. R. NAVARRO MALLEBRERA, Los arquitectos..., op. cit., pp. 55-56. Ver notas 19 y 20.

81 Ver nota 32. El 20 de agosto de 1676, Juan "Poquet" renunciaba a la explotación de una heredad que llevaba trabajando unos años. AHME, sig. SHPN 447, f. 153v-154v. Se trataba de "olivars, terres y altres abres ab un ort plantat de palmeres y magraners ab una casa, torre y almacera", a la que renunciaba porque estaba "tan imposibilitat que no pot ni se atrevex a llevar ni conrear la dita heretat". Fauquet hijo era muy joven - 23 años - como para renunciar a una explotación tan ventajosa por estos motivos, por ello pensamos que se trata de su padre.

82 Aparece en multitud de ellas, convirtiéndose en un miembro destacado. J. CASTAÑO GARCÍA, Llibre de la fàbrica..., op. cit., p. 326.

83 "De yeso y piedra", con un grosor "de palmo y tercio", según el reconocimiento efectuado por Salvador de Mora, Pedro Jumilla, Pedro Pagán y Lucas de los Corrales en 1733. R. NAVARRO MALLEBRERA, Los arquitectos..., op. cit., p. 57 


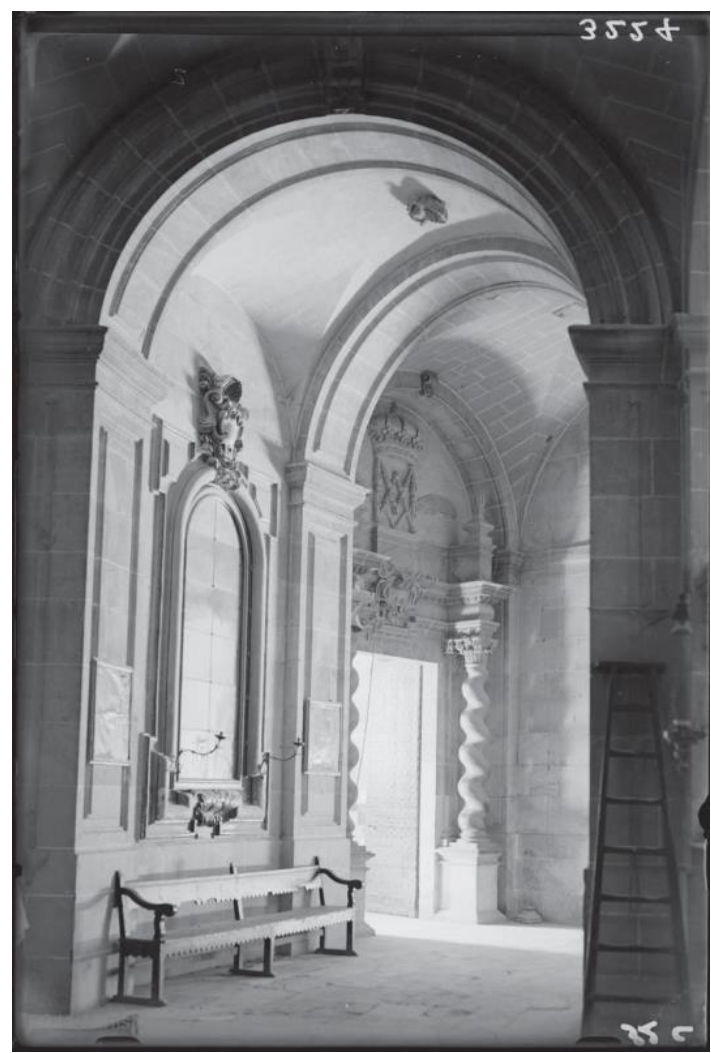

Fig. 6. Deambulatorio de la iglesia de santa María, de Elche (Foto: A. Passaporte. A. Loty, IPCE, MCU).

como templo provisional, si bien tenía avanzadas ya las obras del crucero $^{84}$. También en 1686 rediseñó los planos de este espacio y la cabecera con deambulatorio, así como la capilla de la comunión y la sacristía ${ }^{85}$, donde ideó una magnífica escalera de voltes, muy semejante a la de Inglés para el colegio de santo Domingo de Orihuela ${ }^{86}$. Todas estas trazas fueron revisadas por Melchor Luzón, “mestre d'obres

84 De hecho, en mayo de 1693 la sacristía debía estar finalizada o muy avanzada, pues unos vecinos se quejaron ante el Consell del municipio de que "antes de que se fabricara la sacristía de santa María tenían salida a la puerta de la villa con galeras y cabalgaduras cargadas, ya ora (sic) se hallan privados de esta conveniencia", por lo cual suplican que se abra una nueva calle, lo cual se les concedió el 11 de dicho mes. AHME, sig. a 58, s/f.

85 R. NAVARRO MALLEBRERA, Los arquitectos ..., op. cit., pp. 55-59. R. NAVARRO MALLEBRERA, "La capilla de comunión de santa María, de Elche: su proceso constructivo", Archivo de Arte Valenciano, n. ${ }^{\circ} 45,1974$, pp. 56-60.

86 Y.SPAIRANI-BERRIO, op. cit., p. 109. 
iengenyer real"87, y Juan Blas Aparicio, "profesorde matemàtiques iregentdel 'obrade l'esglèsia major de Xàtiva".

La identidad de este religioso, mossén Juan Blas Aparicio y Polop, nacido hacia 1653, ha sido confundida con la de un ilustre catedrático de matemáticas de la Universitat de València, el fraile mercedario Juan Aparicio, que había nacido en Enguera en $1635^{88}$. No obstante, se ha seguido señalando este mismo origen para Juan Blas, de modo que si fue también enguerino ${ }^{89}$, no debe escapársenos que pudo recibir junto a Fauquet una temprana formación de manos de Francisco Verde, avecindado allí. De ser cierta esta hipótesis se comprendería mejor el importante cambio que generó Aparicio en la arquitectura de su momento, "poniéndola a la altura de las reformas que por esos años se operaban en el medio novator" al abrir "una alternativa barroca y de claro abolengo matemático" con la construcción de la colegiata de Xàtiva, al mando de la cual estuvo entre 1683 y 1705. Del mismo modo, tomaría un nuevo sentido la resolución estereotómica "compleja y moderna", de "calculada torsión geométrica", que Fauquet imprime en el deambulatorio de la iglesia ilicitana (Fig. 6) $)^{90}$, y que respondería a una formación o bagaje similares.

Si este contacto de 1686 entre Fauquet y Aparicio pudo no ser el primero, tampoco fue el último, puesto que en 1697 ambos presentaron proyectos para la reconstrucción del pantano de Tibi, siendo finalmente elegido el del religioso ${ }^{91}$. Por su parte, Fauquet ya había abordado cuestiones hidráulicas, pues en enero de 1689 había realizado una declaración junto a José Marfil, ambos como "mestres ingeniers", sobre

\footnotetext{
87 Ingeniero, arquitecto, pintor y escultor (Teruel, 1625 - Murcia, 1698). Entre 1658 y 1672 desarrolló su faceta arquitectónica, participando de grandes obras como la colegiata de san Patricio, de Lorca (1658), y el santuario de Caravaca de la Cruz (1661-1669). J. MARTÍNEZ VERÓN, Arquitectos en Aragón..., op. cit., p. 375. En 1683 se le requirió en Orihuela para el encauzamiento del río Segura. J. OJEDA NIETO, "Encauzamientos y mudamientos del río Segura en Orihuela durante los siglos XVI y XVII", Cuadernos de Geografia, n. ${ }^{\circ}$ 79, 2006, pp. 1-18.

88 Sin deslindar ambas identidades, hablaron sobre él J. BÉRCHEZ, Arquitectura barroca ..., op. cit., pp. 28-34; M. SIMÓN MARTÍNEZ, "La villa de Enguera en el s. XVII", en Aproximación a la historia de Enguera, Ayuntamiento, Enguera, 1994, p. 204; P. GONZÁLEZ TORNEL, op. cit., pp. 81-88.

89 La confusión entre ambos Aparicio fue corregida en J. BÉRCHEZ y M. GÓMEZ-FERRER, La Seo de Xàtiva: Historia, imágenes y realidades, Institut Valencià de Conservació i Restauració de Béns Culturals, Valencia, 2007, p. 67, gracias a las aportaciones de C. PEÑA VELASCO, El puente viejo de Murcia, Universidad de Murcia, Murcia, 2001, p. 54. No obstante, siguen señalando a Enguera como lugar de nacimiento de Juan Blas. Sea o no una extensión de la confusión, hay que apuntar que el apellido "Aparicio" era extremadamente común entre los enguerinos, y ocasional "Palop", lo cual se advierte en la consulta a sus fondos parroquiales y en el vecindario de 1646 analizado por P. GARZÓN SERRANO, op. cit., 1994, p. 232. En los libros sacramentales no hemos hallado su bautismo ni tampoco su confirmación.

90 J. BÉRCHEZ y M. GÓMEZ-FERRER, La Seo de Xàtiva ..., op. cit., p. 67.

91 E. CAMARERO CASAS (et. al.), Tibi, un pantano singular, Generalitat Valenciana, Valencia, 1989, p. 35.
} 
el estado del pantano de Elche ${ }^{92}$; mientras que en 1693 presentó dos proyectos para evitar su cierre ${ }^{93}$. Se conserva además un diseño autógrafo de estas características, en concreto una "planta de una raja en la rambla para el molino del río de Aspe"94.

Las escasas noticias sobre Fauquet parecen sugerir un carácter sedentario, y de hecho renunció a la única obra que habría requerido un distanciamiento prolongado de su hogar en Elche: la construcción del templo de las Agustinas deAlmansa, que contrató en enero de 1701, pero que tan solo dos meses después pasó a Martín de Armendia — con quien había coincidido años antes alrededor de Pedro Quintana- y Nicolás Fernández. Ambos habrían de seguir las trazas y capitulaciones de Fauquet ${ }^{95}$, en las que demuestra un amplio dominio en el planteamiento del tabicado, pues el principal material utilizado sería el ladrillo, tanto para los muros como para los arcos, bóvedas y cúpula.

Este modo constructivo a base de ladrillos fue representativo de la renovación técnica que se produjo en la arquitectura valenciana del último tercio del XVII, y que tiene en Pérez Castiel uno de sus mejores exponentes ${ }^{96}$. Precisamente este maestro lo había utilizado en el Puig, directamente supervisado por Verde. Así, Fauquet pudo heredar este conocimiento de su abuelo, pues si ya había cubierto el cuerpo de naves de santa María con bóvedas de mampostería — de cañón con lunetos-, las proyectó del mismo tipo pero tabicadas, "a la romana", en Almansa, solución que también popularizó Juan Pérez ${ }^{97}$.

La cercanía con las formas de este arquitecto no se agota en las técnicas constructivas, pues también se aprecia en la portada principal del templo de Almansa,

\footnotetext{
92 AHME, sig. a 44, s/f. Este José Marfil pudo estar emparentado con los hermanos Juan y Matías Marfil, carpinteros murcianos vinculados con la construcción de los puentes de aquella ciudad. El primero, carpintero "inteligente en obras de agua", presentó en 1702 una planta para el nuevo puente sobre el río Segura, en Murcia, que fue evaluada por Juan Blas Aparicio y por Vicente Soler; además, los dos hermanos intervinieron en 1726 en el azud mayor de Murcia. C. PEÑA VELASCO, "Religiosos arquitectos y matemáticos...", op, cit., pp. 250-251, 260.

93 AHME, sig. a 46, s/f.

94 AHME, sig. b 22, s/f.

95 P. CLEMENTE LÓPEZ, "El proyecto de Juan Foquet y Verde en la iglesia de las agustinas de Almansa", en II congreso de Historia de Albacete, Instituto de estudios albacetenses, Albacete, 2002, vol. III, p. 344. P. CLEMENTE LÓPEZ, El convento de las Agustinas de Almansa: historia y arte, Instituto de estudios albacetenses, Albacete, 2005, p. 56.

96 M. GARCÍA LISÓN y A. ZARAGOZÁ CATALÁN, "Iglesia parroquial de Nuestra Señora de los Ángeles. Tuéjar", en Catálogo de monumentos y conjuntos de la Comunidad Valenciana, J. BÉRCHEZ (coord.), Conselleria de Cultura, Valencia, 1983, p. 222.

97 J. BÉRCHEZ, Arquitectura barroca ..., op. cit., p. 38.
} 
rotulada en 1704, similar a las de las parroquiales de San Andrés de Valencia (16841686), Alzira (ca. 1681) o Torrent (1697) ${ }^{98}$, proyectadas o al menos relacionadas con Pérez ${ }^{99}$; así como con otros ejemplos del área murciana, como la puerta del palacio de Guevara en Lorca (1692), insistentemente atribuida a Bussy ${ }^{100}$.

El ático de la portada de Almansa describe también interés. Ya se advirtió su deuda - y la de las ventanas de la casa Mergelina o de la casa consistorial (ca. 1707) de Villena ${ }^{101}$ — con las fachadas del crucero de la colegiata de Xàtiva, a su vez proyectadas y concluidas hacia 1700 por el maestro Aparicio, siguiendo la arquitectura oblicua ${ }^{102}$. La repercusión de este modelo de edículo, de entablamento curvado y pilastras declinadas, no se agotó en estos ejemplos, pues puede verse también en fachadas murcianas como la del convento de santo Domingo (ca. 1742) ${ }^{103}$, a donde pudo llegar a través de los diseños de maestros itinerantes, entre ellos, el del oriolano José Ganga Ripoll (1698-1759) para el retablo del convento de santa Ana (1738) ${ }^{104}$.

Regresando a Fauquet, cedió la construcción de las Agustinas "por hallarse con diferentes obras"105, si bien las de Santa María estaban detenidas. Desconocemos más datos sobre su actividad en este momento, y si ese sedentarismo que le suponemos es causa o efecto de ello, pero hacia 1707 vuelve a trabajar en Elche ininterrumpidamente hasta su muerte. De manera excepcional, en 1716 reconoció y consolidó junto con

\footnotetext{
98 P. CLEMENTE LÓPEZ, El convento de las agustinas..., op. cit., pp. 71-87.

99 Y que se han considerado derivaciones de los frontispicios del presbiterio de la catedral valenciana. M.A. CATALÀ GORGUES, "Iglesia de san Juan de la Cruz", en Catálogo de monumentos y conjuntos de la Comunidad Valenciana, J. BÉRCHEZ (coord.), Conselleria de Cultura, Valencia, 1983, p. 517. F. PINGARRÓN, op. cit., pp. 158-159. J. BÉRCHEZ y M. GÓMEZ-FERRER, "Iglesia de san Juan de la Cruz, antigua san Andrés", en Monumentos de la Comunidad Valenciana. Valencia, arquitectura religiosa, J. BÉRCHEZ (coord.), Conselleria de Cultura, Valencia, 1995, pp. 172-181.

100 M.C. SÁNCHEZ-ROJAS FENOLL, El escultor don Nicolás de Bussy, op. cit., p. 47. Posteriormente J. SÁEZ VIDAL, Retablos y retablistas barrocos de Orihuela, Diputación Provincial, Alicante, 1998, pp. 75-78, la atribuía a Antonio Caro Bernabé. De forma reciente, M.C. SÁNCHEZ-ROJAS FENOLL, "La etapa murciana de Nicolás de Bussy", en Nicolás de Bussy: un escultor europeo en España, Real Academia de Bellas Artes, Murcia, 2006, p. 109, señalaba que esta portada podría deberse a la colaboración entre Bussy y los Caro. En la misma línea, vinculándola además a los escultores José Villanueva y a Sánchez Eslava, se pronuncia P. SEGADO BRAVO, Lorca Barroca, Editum, Murcia, 2012, p. 421-428.

101 F. BENITO DOMENECH y J. BÉRCHEZ, "Palacio municipal. Villena", en Catálogo de monumentos y conjuntos de la Comunidad Valenciana, J. BÉRCHEZ (coord.), Conselleria de Cultura, Valencia, 1983, pp. 885-892.

102 D. VILAPLANA ZURITA, "Influencias del tratado de Caramuel en la arquitectura de la colegiata de Xàtiva", Archivo de Arte Valenciano, n. ${ }^{\circ}$ 66, 1985, p. 63. BÉRCHEZ y GÓMEZ-FERRER, La Seo de Xàtiva ..., op. cit, pp. 82-83.

103 P. CLEMENTE LÓPEZ, El convento de las agustinas..., op. cit., p. 80. El convento de santo Domingo "es de 1742”, según A.E. PÉREZ-SÁNCHEZ, Murcia-Albacete y sus provincias, Aries, Barcelona, 1961, p. 81

104 Sobre este retablo véase C. PEÑA VELASCO, El retablo barroco en la antigua diócesis de Cartagena, 1670 1785, Colegio de aparejadores y arquitectos, Murcia, 1992, pp. 313-318; y J. SÁEZ VIDAL, Retablos y retablistas barrocos..., op. cit., pp. 160-165.

105 P. CLEMENTE LÓPEZ, El convento de las agustinas..., op. cit., p. 56.
} 
Francisco Mingot la maltrecha cúpula de San Nicolás de Alicante ${ }^{106}$, aunque hay quien apunta que solo participó de su proyección para que fuera ejecutada por el segundo ${ }^{107}$.

Fauquet murió el 19 de febrero de $1719^{108}$. En 1745 su hijo José vendió a la parroquia los planos que el padre había trazado de la iglesia, con el objetivo de acometer la construcción de la capilla de la comunión siguiendo la planta mostrada en aquellos — si bien fueron modificados - . De hecho, el crucero no estaba cerrado. A partir de 1720 se hizo cargo de ello fray Francisco Raimundo, otro de estos arquitectos e ingenieros de vasto dominio técnico ${ }^{109}$, que concluyó la cúpula que se mantuvo en pie hasta 1903, cuando fue desmontada y sustituida por una nueva con estructura de hierro para aliviar su peso.

La obra de los artífices que hemos tratado, que resultó fundamental en la difusión y consolidación de maneras y estilos, se enmarca en una compleja red de lugares comunes, relaciones personales y contactos profesionales, donde cobra relieve el papel aún inexplorado de órdenes religiosas como la mercedaria. Aquellos y sus variopintas cuadrillas pusieron en práctica una renovada tradición arquitectónica clasicista, de valor estereotómico, fuerte componente matemático y geométrico, en obras edilicias y también hidráulicas, estas tan frecuentes y necesarias en el litoral mediterráneo. Al mismo tiempo, participaron de la actualización técnica que se producía en aquellos momentos, y que a su vez estaba comprometida con el desarrollo y la implantación de un nuevo lenguaje decorativo, considerado en el momento de estricta vanguardia y elevada categoría.

\footnotetext{
106 I. VIDAL BERNABÉ y R. NAVARRO MALLEBRERA, "San Nicolás. Alicante”, op. cit., p. 97. J. SÁEZ VIDAL, El arte barroco en Alicante, 1691-1790, Instituto Juan Gil-Albert, Alicante, 1985.

107 P. CLEMENTE LÓPEZ, El convento de las agustinas..., op. cit., p. 55. Puede no ser casual que en febrero del año siguiente se documente en Elche a un tal Miguel Mingot, "residente de la ciudad de Alicante". AHME, sig. SHPN 965, f.16-16v.

108 Por desgracia no hemos hallado su testamento, pero sí el de su primera esposa, María Zaragoza, con quien tuvo a Fulgencio - "Flujencio"- - y que debió fallecer en el parto del siguiente de sus hijos, pues testó a punto de dar a luz, el 13 de diciembre de 1681. AHME, sig. SHPN 329, f. 59v-61v. Posteriores noticias nos presentan al primogénito realizando gestiones sobre la herencia para sus hermanos Josefa, Juana y José. AHME, sig. SHPN 652, f. 409-409v, 413-413v.

109 R. NAVARRO MALLEBRERA, "La capilla de la comunión...”, op. cit., pp. 56-57. R. NAVARRO MALLEBRERA, Los arquitectos..., op. cit., pp. 59. Sobre Raimundo, C. PEÑA VELASCO, "Religiosos arquitectos y matemáticos...", op, cit., pp. 257-263.
} 